\title{
NUTRITION AND METABOLISM
}

\section{7}

ZINC ABSORPIION IN AND DURING RECOVERY IROM SI:VIERI MALNUTRITION IN CHILDHOOD. Barbara E Golden \& Michat HIN Golden (spn.

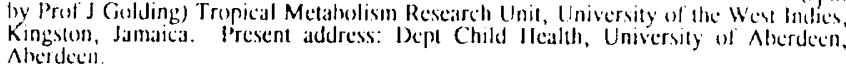

Severely malnourished Jamaican children have evidence of both malahorption and an (Zn) deficiency, especially when they are oedematous. However, on high energy feeds they are able wo gan weight at greally accelerated rattes. By labelling their feeds with

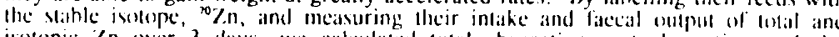
isotopic $\angle n$ over 3 days, we calculalled lotal absorption, net absorption and, by difference, endogenous loss of $\mathrm{Zn}$ in groups of children, 8 16 19 montls wh, with

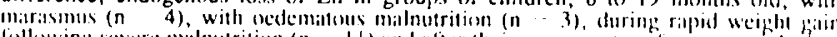

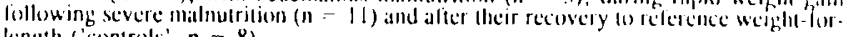
length ('controls', $n=8$ )

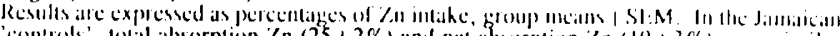

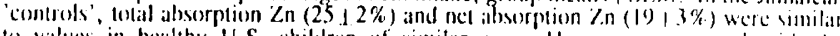
to vilues in healthy U.S children of simitar age. However, complated with the

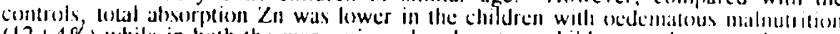

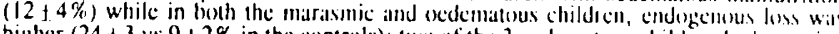
higher $(24+3$ vs $9+2 \%$ in the controls): two of the 3 cedematous children had negative net alsworption Zn. During rapid weight bain, nel absorpleten $\angle n(27,2 \%)$ wis ligher llan in the controls and correlated pesitively with their ralc of weight gian (1 0.74 $p<0.0 \mid)$ : their condogenous loss was low $(5,2 \%)$

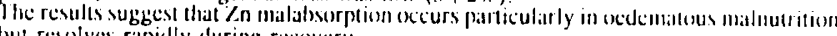
but resolves rapidly during recovery.

\section{8}

EVALUATION OF THE BODY COMPOSITION AND THE BONE MINERAL CONTENT BY DUAL X RAY ABSORPTIOMETRY. A. LAPILLONNE*, B.L.SALLE*, P.BRAILLON\$̧, M.CIIAMBON*. Department of Neonatology* and Rhumatology§ Ilopital Edouarú llerriot, LY'ON, FRANCE

An Ilologic QDR $1000 \mathrm{~W}$ system equiped with a special pediatric scanning program was used to evaluate total bone mineral content (BMCl), lean body mass and fat content. 65 infants were studied, gestational age ranged from 36 to 40 wecks : 28 were appropriate for gestational age (AGA), 24 were sniall for gestational age (SGA) and 13 were infants of diabetic mothers (IDM). Mean birh weight (BW) \pm SD wis $3116 \pm$ $557,2015 \pm 184$ and $3601 \pm 535$ grams; mean length \pm SD wits $49.2 \pm 2.5 .44 .8 \pm$ 1.9 and $49.8 \pm 2.9 \mathrm{~cm}$ respectively. The scian was performed during the first diy of life. BMCl (urams of hydroxyapatie), lean body miss (grams), fat content (urams) $q$ BMCt, \% fat and \% lean mass were (results were expressed as mean \pm SD)

MCt, \% fat and \% lean mass were (results were expressed as mean \pm SD) :
\[ G A(n=28) \quad \text { SGA }(n=24) \]

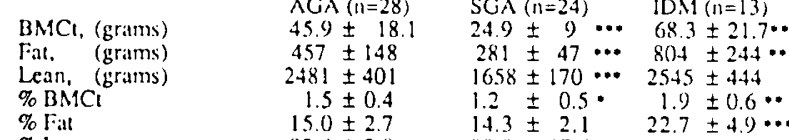

$\%$ 列 $14.3 \pm 2.1 \quad 22.7 \pm 4.9 \cdots$
- $p<0.05 \cdots p<0 .(0) 1 \cdots p<0.0(0) 1$. AGA vs SGA, AGA vs IDM.

In this gestational age range (36-40 weeks), 1) BMCt in $A G A$ group differed from both SGA and IDM cillegories: BMCt wits beller correlated with birthweight than with gestational age. 2) Body composition in \% of BW did not differ significimly between SGA and AGA infants. 3) In IDM infants, fat content increased and thus explained the heavy birthweight.

\section{0}

FIRST TRIMESTER PHENYLKETONURIA (PKU) DIETARY CONTROL AN MEURODEVELOPMENTAL OUTCOME IN INFAHTS, Ann Lorek, Jemy Baudth, Jal Towneend, Maggie Lilburn, Ann Stewart and David Brenton. Depts of Paediatrics and Medicine, University College London Medical School, London, uk.

To avoid fotal damage in women with PKU, Btrict preconception and pregnancy control of blood phenylalanine concentratiuns (PHE) have boen recommended (2). To find out if these reconmendations prevented neurological damage we etudied the neurodevelopmental outcome of 24 infants from 23 pregnancies in which strict dietary control was introduced prlor to conception. 18 had reached i year. Measures of 300 mol/l in the to mean PHE, and to number of daye PHE exceeded $300 \mu \mathrm{mol} / 1$ in the firet trimester. They included head circumference quotient (Grifflthe GQ) at 1 year. The ofC etandard deviation ocores (SDS) at term and 1 year in infants of mothers with mean PHE $\$ 300$ (305496) $\mu$ mol / 1 were igniflcant ly maller than those with mean PHE of $<300$ (139-281) $\mu \mathrm{mol} / 1$ (p<0.05). Within the group with mean $\mathrm{PHE}<300 \mu \mathrm{mol} / 1$, OFC SDS was lower in those whose PHE exceeded $300 \mu \mathrm{mol} / 1$ for more than 10 days $(p<0.05) .17$ of the 24 infants examined at term, and 13 of the 28 at 1 year, had abnormal nourological gigne. The mean GQ of these 18 infant was $109 \pm 13$ and did not differ according to PHE. We conclude that a) mean PHE of $<300 \mu \mathrm{mol} / 1$ in the first trimeater improves head growth ospecially when control is otrict b) otrict control at this 1. MRC Working Party on PKU. Arch Dis Child 1993;68:426-427.

\section{9}

THE SERUM TRANSFERRIN RECEPTOR AS INDICATOR OF IRON DEFICIENCY IN INFANTS

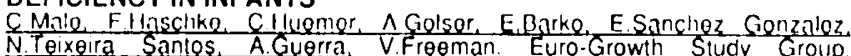
Coordinating Center: Dept. Pediatrics. Univ. Vienna. Austria

Objective: Serum transferrin receptor is now well established in adults as index of iron status. It increases with tissue iron need and is more sensitive than othe parameters to mild iron deficiency. The purpose of this study was to test its value in infants, a population especially susceptible to iron deficiency.

Methods and setting: Wo measured hemoglobin, serum ferritin (RIAgnost, Behring) and the serum transterrin receptor (CLINIGEN EIA. Amgen Diagnostics) in 71 healthy infants at 12 months of age from 5 centers of the Euro-Growth Study (Vienna, Salzburg, Budapest, Bilbao, Porto, Dublin).

Results: Intra- and interassay variances of the transferrin receptor (TfR) Results: Intra- and interassay variances of the transferrin receptor (TfR)
measurements were $3.5 \%$ and $7.75 \%$, respectively. Infants with hemoglobin measurements were $3.5 \%$ and $7.75 \%$, respectively. Infants with hemoglobin
$(\mathrm{Hb})$ levels $<11 \mathrm{~g} / \mathrm{dl}$, indicating anemia, had significantly higher TRR values than (Hb) levels $<11 \mathrm{~g} / \mathrm{dl}$, indicating anemia, had significantly higher TfR values than
infants with $\mathrm{Hb}$ values $>11 \mathrm{~g} / \mathrm{dl}(3.46+0.99 \mathrm{vs} 2.66+1.04 \mathrm{ug} / \mathrm{ml} ; p<0.05$. Wilcoxon infants with $\mathrm{Hb}$ values $>11 \mathrm{~g} / \mathrm{dl}(3.46 \pm 0.99 \mathrm{vs} 2.66 \pm 1.04 \mathrm{ug} / \mathrm{ml} ; \mathrm{p}<0.05$. Wilcoxon
rank test). In infants with $\mathrm{Hb}>11 \mathrm{~g} / \mathrm{dl}$ and s-ferritin $<12$, between 12.20 and $>20$ rank test). In infants with $\mathrm{Hb}>11 \mathrm{~g} / \mathrm{dl}$ and s-territin $<12$, between $12 \cdot 20$, and $>20$
$\mathrm{ng} / \mathrm{ml}$, TiR values were $3.04 \pm 1.13^{\circ}, 2.54 \pm 0.93$ and $2.18+0.64^{\circ} \mathrm{ug} / \mathrm{ml}$, $\mathrm{ng} / \mathrm{ml}$, TfR values were $3.04 \pm 1.13^{*}, 2.54 \pm 0.93$ and $2.18 \pm 0.64^{\circ} \mathrm{ug} / \mathrm{ml}$,
respectively (" $p<0.05$, Duncans Multiple Range test). Regression analysis did respectively ( $p<0.05$, Duncans Multiple Range test). Regression analysi
not reveal a negative correlation between TfR and either $\mathrm{Hb}$ or s-territin. Conclusions: Serum transterrin receptor is significantly increased in infants with iron deficiency anemia. in infants with no anemia $(\mathrm{Hb}>11 \mathrm{~g} / \mathrm{dl})$ but low iron stores (s-ferritin < 20) elevated transferrin receptor values already indicate iron deficient erythropoeisis. Although our data are limited the combination of serum ferritin and serum transferrin receptor appears promising as a screening tool for mild iron deficiency in inlants.
141

PROTEIN METABOLISM IN VENTILATED PRETERM INFANTS ON THE FIRST DAY OF LIFE.

J.B. Van Goudoever, J.L.D. Wattimena, P.J.J. Sauer. Department of Pediatrics, Sophia Childrens Hospital, Erasmus University Rotterdam, The Netherlands.

Protein kinetics were measured to examine the effect of immediate commencement of amino acid (AA) administration following birth. Eight infants (birth wt $1.5 \pm 0.3 \mathrm{~kg}$ ) received exclusively $6.6 \pm 1.4 \mathrm{~g}$ glucose $/ \mathrm{kg} / \mathrm{d}(26 \mathrm{kcal} / \mathrm{kg} / \mathrm{d})$ and seven infants (bw $1.4 \pm 0.4 \mathrm{~kg}$ ) received $5.9 \pm 2.0 \mathrm{~g}$ glucose $/ \mathrm{kg} / \mathrm{d}$ and $1.2 \pm 0.1$ g AA/kg/d $(28 \mathrm{kcal} / \mathrm{kg} / \mathrm{d})$. All infants were ventilated and studied at the first day of life. A primed continuous infusion of $\mathrm{NaH}^{13} \mathrm{CO}_{3}$ was followed by a primed continuous infusion of $\left[1^{13} \mathrm{C}\right]$ leucine. Isotopic enrichment of expired $\mathrm{CO}_{2}$ was measured by IRMS and dilution of ${ }^{13} \mathrm{C}-\mathrm{KIC}$ was measured by GCMS. Nitrogen excretion was measured in urine. The results (mean $\pm S D,+$ sign.diff. at $p \leq 0.01)$ : $\mathrm{N}$-balance Turnover Oxidation Synthesis Breakdown Balance $\mathrm{mg} / \mathrm{kg} / \mathrm{d} \longrightarrow \mu \mathrm{mol}$ leucine $/ \mathrm{kg} / \mathrm{hr}$

glucose $\quad-110 \pm 47 \quad 201 \pm 20 \quad 41 \pm 13 \quad 160 \pm 20 \quad 186 \pm 20 \quad-27 \pm 13$ $\mathrm{glu}+\mathrm{AA}+45 \pm 98+219 \pm 33 \quad 48 \pm 16 \quad 171 \pm 35 \quad 171 \pm 35+4 \pm 17 \dagger$ Cenclusions: 1. Amino acid administration does not significantly alter leucine oxidation on the first day of life. 2. Even at a very low energy intake, amino acid administration of $1.2 \mathrm{~g} / \mathrm{kg} / \mathrm{d}$ prevents both negative leucine and nitrogen balances. Based upon protein balances, it seems that the administration of amino acids on the first day of life is benificial for preterm infants.
142

MIXED MCT/LCT LIPID EMULSION USE IN SICK VLBW INFANTS David C Wilson, Henry L llalliday, Mark Reid, Garth McClure, John A Dodge. Department of Child Health, The Queen's University of Belfast and Royal Maternity spital, Belfast.

Undernutrition is common in sick VLBW infants requiring parenteral nutrition (PN). Lipid-free PN leads to poor energy intake but lipid has been associated with increased incidences of infection and BPD. Medium chain

triglycerides (MCT) are metabolised faster than long chain (LCT). We therefore designed a new PN regimen, with use of a 50 i MCT emulsion from day 2 and in greater amounts and compared this to a conventional pN regimen with LCT compared this to a conventional PN regimen with 100 s new PN regimen (MCT) or control (LCT) groups; Lipof und in MCT/LCT (B Braun) was used in the MCT group $(n=64)$ and Intralipid (Kabi vitrum) in the LCT group $(n=61)$. The MCT group had a mean BW of $925 \mathrm{~g}$ compared to $933 \mathrm{~g}$ in the LCT group had a mean $\mathrm{BW}$ of $925 \mathrm{~g}$ compared to $933 \mathrm{~g}$ in the
group. Mean energy intakes whilst receiving $\mathrm{PN}$ were greater $(p<0.001)$ in the MCT group at days $7,14,21,28,35$ and 42. The incidences of BPD were 29 in the MCT group and 29 in the LCT group (ns), with infection rates of 638 and 748 respectively (ns). There were no significant increases in incidences of hyperlipidaemia or hyperketonaemia in the MCT group. We conclude that liveral MCT emulsion usage lessens undernutrition without adverse clinical or metabolic sequelae in sick preterms. 